\title{
Preliminary study of soot and polycyclic aromatic hydrocarbons in emitted particles from adobe kilns that use scrap tires as fuel
}

\author{
Brenda L. VALLE-HERNÁNDEZ, Estheisy LÓPEZ-BELLO, Miguel TORRES-RODRÍGUEZ, \\ Cecilia AGAPITO-ABRAHAM and Violeta MUGICA-ÁLVAREZ*
}

Área de Química Aplicada, Departamento de Ciencias Básicas, Universidad Autónoma Metropolitana-Azcapotzalco, Ave. San Pablo 180, Col. Reynosa Tamaulipas, 02200 Ciudad de México, México.

*Corresponding author; email: vma@azc.uam.mx

Received: August 20, 2019; accepted: February 5, 2020

\begin{abstract}
RESUMEN
La alfarería artesanal en México se fabrica principalmente en hornos de adobe hechos a mano, utilizando llantas de desecho como principal combustible en áreas rurales y periurbanas, lo que convierte a esta actividad en una de las principales fuentes de contaminantes atmosféricos. Se realizó una campaña intensiva de muestreo en un pequeño poblado mexicano con el fin de caracterizar las especies tóxicas emitidas por más de 400 hornos de adobe que funcionan durante dos escenarios: baja actividad y actividad normal, así como determinar su potencial carcinogénico. Las concentraciones de $\mathrm{PM}_{10}$ fluctuaron de 50 a $80 \mu \mathrm{g} \mathrm{m}^{-3}$ y de 77 a $290 \mu \mathrm{g} \mathrm{m}^{-3}$ durante los períodos de actividad baja y normal, respectivamente, mientras que las concentraciones de $\mathrm{PM}_{2.5}$ variaron de 33 a $57 \mu \mathrm{g} \mathrm{m}^{-3}$ y de 37 a $177 \mu \mathrm{g} \mathrm{m}^{-3}$, respectivamente, en el mismo periodo. El carbono orgánico y el carbono elemental presentaron concentraciones alrededor de cuatro y siete veces mayores, respectivamente, durante el periodo de actividad normal respecto al periodo de baja actividad en ambos tamaños de partículas. Los hidrocarburos aromáticos policíclicos (HAP) cuantificados fueron dos veces mayores durante el periodo de actividad normal que en el periodo de baja actividad. Los HAP cancerígenos representaron de 53 a $59 \%$ del total de HAP en todos los casos y su potencial cancerígeno (B $[a] \mathrm{Peq})$ en $\mathrm{PM}_{10}$, durante la actividad normal, fue 25 veces mayor que el valor recomendado por la Comisión Europea, lo que demuestra el alto riesgo que tiene la población cercana por estar expuesta a esas emisiones.
\end{abstract}

\begin{abstract}
Artisanal pottery in Mexico is largely manufactured in handmade adobe kilns using scrap tires as main fuel in rural and periurban areas, making this activity one of the main sources of atmospheric pollutants. An intensive sampling campaign was conducted in a Mexican small town in order to characterize the toxic species emitted by more than 400 adobe kilns working in two scenarios: low and normal activity, as well as to determine their carcinogenic potential. $\mathrm{PM}_{10}$ concentrations ranged $50-80 \mu \mathrm{g} \mathrm{m}^{-3}$ and $77-290 \mu \mathrm{g} \mathrm{m}^{-3}$ during low and normal activity periods, while $\mathrm{PM}_{2.5}$ concentrations were $33-57 \mu \mathrm{g} \mathrm{m}^{-3}$ and $37-177 \mu \mathrm{g} \mathrm{m}^{-3}$ in the same periods. Organic carbon and elemental carbon presented concentrations around four and seven times greater, respectively, during a normal activity period than during a low activity period in both particle sizes. Quantified polycyclic aromatic hydrocarbons were twice greater during the normal activity period than during the low activity period. Carcinogenic PAHs accounted for $53-59 \%$ of total PAHs in all cases and the carcinogenic potential (B[a]Peq) in $\mathrm{PM}_{10}$ during the normal activity was 25 times higher than the European Commission recommendation, proving thereby the high risk that nearby population faces to those emissions.
\end{abstract}

Keywords: adobe kilns, carcinogenic potential, PM, PAHs, scrap tires. 


\section{Introduction}

Over the last years, several studies related to the brick kiln emissions have been published due to their impact on air quality and health on nearby population (Le and Oanh, 2010; Ames et al., 2012; Skinder et al., 2014; INECC, 2016) Quite the opposite and to the best of our knowledge, no research has addressed the study of adobe kiln emissions which are used by pottery artisans in many regions of developing countries. The word "adobe" is used to describe various earthen-based building materials and techniques usually referring to the sun-dried adobe brick, rammed-earth construction that is widely used in developing countries (Binici et al., 2005; Millogo et al., 2014). Adobe kilns have been used since the pre-Hispanic era in Mexico by artisans (Ruvalcaba-Sil et al., 1999), with 9749 registered pottery workshops in the country (INEGI, 2017). In the Temascalcingo municipality of the State of Mexico, pottery is an informal familial industry that represents the main activity of many towns located in urban and rural areas, most of them installed in the households' backyards (INEGI, 2017). Although the traditional fuel in an adobe oven is firewood, due to the scarcity of this raw material and the high cost of gas and diesel, wasted tires (which are banned as a fuel in Mexico) are the most used fuel in adobe ovens, basically because they are cheap, consequently giving rise to multiple small smoky chimneys in artisans towns, similar to those observed in artisanal brick production areas (Williams, 2018). According to the Secretaría del Medio Ambiente y Recursos Naturales (Ministry of Environment and Natural Resources) of Mexico, every year more than 32 million used tires are discarded, representing on the one hand a waste problem, but on the other hand an opportunity to have a low cost fuel like that for brick kilns (INECC, 2016). Tires are mainly composed by a mixture of several rubbers strengthened with carbon black filler material, usually styrene-butadiene copolymers or styrene-butadiene copolymer/polybutadiene mixtures (62.1\%), black carbon (31\%), extender oil (1.9\%), and other additives (4.9\%) (Caponero et al., 2003). Several researchers have identified some PAHs in tires such as Flt, Phe and Pyr (Rogge et al., 1993). PAHs may have petrogenic origin when they are related with crude oil and subproducts, or pyrogenic origin when they are associated to fossil fuels or combustion processes, usually dominated by unsubstituted high molecular weight PAHs (Wang et al., 2007; González-Sepúlveda et al., 2013). Boonyatumanond et al. (2007) reported high correlations of Pyr and $\mathrm{BghiP}$ with tire residues, which are likely derived from extender oils used to make tires, whereas Atal et al. (1997) detected petrogenic PAHs $>178 \mathrm{~g} \mathrm{~mol}^{-1}$ (Phe, Ant, Flt, Pyr, BaP, among others) in constituents of waste tires, but due to their complicated extraction with a high uncertainty they were not quantified; however, these researchers reported that parent PAH survivability is a minor path for PAH emissions at fuel-rich conditions as is the case of adobe kilns. Waste tires are attractive products to be recycled as fuel, due to their high calorific power of 29-39 $\mathrm{MJ} \mathrm{kg}^{-1}$ (Giere et al., 2004) which is greater compared with the $27 \mathrm{MJ} \mathrm{kg}^{-1}$ of carbon (Pirnie, 1991). Nevertheless, combustion processes, utility boilers and kilns using this kind of fuel should be designed and optimized in order to avoid air pollution problems (Barlaz et al., 1993; Caponero et al., 2003, 2005).

It is a well-known fact that uncontrolled burning of tires produces high emissions of pollutants, greenhouse gases, and particulate matter (PM) containing carbonaceous species such as elemental carbon (EC) (named also black carbon or soot), which increase the radiative forcing contributing to global warming, along with toxic organic species, as polycyclic aromatic hydrocarbons (PAHs) and dioxins included in the organic carbonaceous fraction (OC) of PM (DeMarini et al., 1994; Reisman et al., 1997; Lemieux et al., 2004; Downard et al., 2015). Although tire particles burn faster and hotter than similar-size coal chips and release less $\mathrm{NO}_{x}, \mathrm{SO}_{2}$ and $\mathrm{CO} 2$ than coal, they generate significantly higher PAHs and soot yields (Caponero et al., 2005). Particles and elemental carbon have been associated to lung cancer, respiratory and cardiovascular diseases (Briggs and Long, 2016).

PAHs are semi-volatile species formed via a pyrolytic process during incomplete combustion of carbonaceous materials. Source apportionment studies of these compounds have shown that domestic, gasoline and diesel vehicles and biomass burning are the major sources of PAHs (Ravindra et al., 2008; Mugica et al., 2010; Jakovljević et al., 2018). The United States Environmental Protection Agency (USEPA) selected 16 priority PAHs, among which those of higher 
molecular weight have been classified as carcinogenic and genotoxic, being represented by benzo $[a]$ pyrene as a cancer risk indicator. Several researches have reported that some mutagenic and carcinogenic properties of particles are due to the presence of bonded PAHs (IARC, 1989; Garshick et al., 2004; Pope and Dockery, 2006; Amador-Muñoz et al., 2013; De Oliveira Alves et al., 2014; Mugica-Álvarez et al., 2015; Aztatzi-Aguilar, et al. 2018). Population can be exposed to PAHs inhalation in areas with multiple adobe kilns, but this is determined by the distance from the sources as well as by PM concentration. Child work from family members is common in pottery workshops, exposing children to the adobe kilns emissions. In this regard, Martínez-Salinas et al. (2010) carried out an assessment of children exposure to PAHs from different sources, finding out that highest exposures occurred in rural communities due to indoor and outdoor biomass burning followed by brick kilns manufacture, whereas Alvarado-Cruz et al. (2017) conducted a cross-sectional study of 150 schoolchildren in an industrial urbanized area and observed that increased methylation in DNA repair genes associated with environmental exposure to some PAHs and metals adsorbed in $\mathrm{PM}_{10}$, can contribute to DNA irreparable damage in that age group.

Considering the lack of information about emissions of adobe kilns, the main objective of this investigation was to determine $\mathrm{PM}_{10}, \mathrm{PM}_{2.5}$, carbonaceous and toxic species concentration levels, as well as the carcinogenic potential as benzo $[a]$ pyrene equivalent $(\mathrm{B} a \mathrm{Peq})$ of a PAHs mixture in a town with multiple adobe kilns, in order to provide decision makers with reliable data to design control strategies.

\section{Materials and methods}

\subsection{Sampling site}

Santiago Coachochitlán is one of the 65 small towns of the Temascalcingo municipality located in the State of Mexico, at a medium height above sea level of $2476 \mathrm{~m}\left(19.8622^{\circ} \mathrm{N}\right.$ and $\left.100.034^{\circ} \mathrm{W}\right)$ where climate is predominantly temperate moist with an annual median (10th-90th percentiles) temperature of $15{ }^{\circ} \mathrm{C}$ $\left(7-24^{\circ} \mathrm{C}\right)$ and a rainfall of $700-900 \mathrm{~mm}$, with the dry season lasting from October to May; median (10th90th percentiles) relative humidity during sampling was $31 \%(20-52 \%)$. The town has 3746 inhabitants and the main economic activity is the production of clay handcrafts manufactured in adobe kilns, which mostly use scrap tires as fuel since there is no strict control for this use. The town has around 425 pottery workshops on a surface less than $10 \mathrm{~km}^{2}$, as is shown in Figure 1, being the main source of pollutant emissions to the atmosphere since this community does not have any other type of industry. Additionally, its vehicular

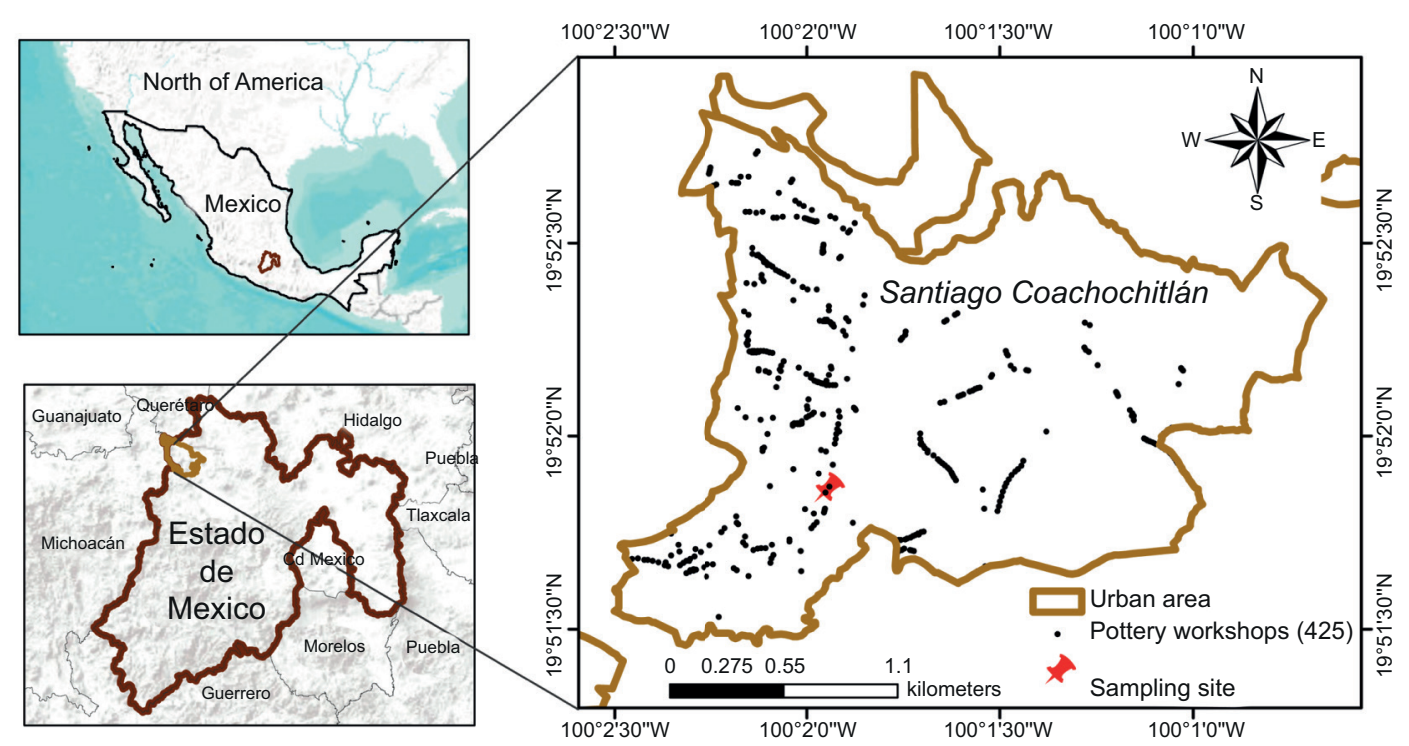

Fig. 1. Santiago Coachochitlán in the State of Mexico. Sampling site and adobe kilns. 
park is not significant, since in the whole Temascalcingo municipality the vehicular fleet reported in 2017 was 14103 vehicles; then, the town has less than 500 vehicles. Other registered economic activities are some tortillerias, butchers, small shops and one chicken rotisseries (INEGI, 2017).

\section{$2.2 P_{10}$ and $P M_{2.5}$ mass concentration determina-} tions

Integrated $24 \mathrm{~h} \mathrm{PM}_{10}$ and $\mathrm{PM}_{2.5}$ samples were collected during two weeks from April 22 to May 5, 2017 with four low volume samplers (AirMetrics and Eugene Oregon), two for $\mathrm{PM}_{10}$ and two for $\mathrm{PM}_{2.5}$, calibrated at $5 \mathrm{~L} \mathrm{~min}^{-1}$. In order to have a comparison, the first sampling corresponded to the Easter week, considered low activity (LA), since children are on holidays and most kilns were inactive, whereas during the second week the adobe kilns displayed normal activity (NA), maintained even during weekends. $\mathrm{PM}_{10}$ and $\mathrm{PM}_{2.5}$ were collected in quartz filters (Whatman, $47 \mathrm{~mm}$ ) previously calcined at $800{ }^{\circ} \mathrm{C}$ for $8 \mathrm{~h}$ and stabilized during $24 \mathrm{~h}$ at $24{ }^{\circ} \mathrm{C}$ and $25 \%$ relative humidity.

Daily temperature, relative humidity, velocity and direction wind data within the sampling period were used to evaluate the variations due to environmental conditions related to each day of sampler.

Particle concentrations were obtained by gravimetry using an analytical balance (Mettler Toledo MT5, Max. $5.1 \mathrm{~g}, \mathrm{~d}=1 \mu \mathrm{g}$ ) divided by the total volume of air. The results are reported as concentration in $\mu \mathrm{g} \mathrm{m}^{-3}$ for an average $24 \mathrm{~h}$.

\subsection{Organic and elemental carbon measurements.}

Quantification of elemental (EC) and organic carbon (OC) was performed with a thermo-optic analyzer (Sunset Lab) according to TOT-NIOSH method (Birch and Cary, 1996); briefly, the filter samples were analyzed in two stages: in the first the temperature reached $650{ }^{\circ} \mathrm{C}$ without oxygen for OC quantification, and during the second stage temperature was raised to $800{ }^{\circ} \mathrm{C}$ in order to oxidize the remaining carbon and determine the EC concentration.

\subsection{Evaluation of analytical method efficiency}

The analytical method efficiency was determined through the recovery percent of each compound (\% Rec). The analysis was performed to four filters, two of $\mathrm{PM}_{10}$ and two of $\mathrm{PM}_{2.5}$, with an added mass of $150 \mathrm{ng}$ (Table I). The recovery percentages varied

Table I. Polycyclic aromatic hydrocarbons and recovery percentages (mean \pm standard deviation).

\begin{tabular}{lllccrr}
\hline & PAH & ID & $\begin{array}{c}\text { Target ion } \\
\mathrm{m} / \mathrm{z}\end{array}$ & $\begin{array}{c}\text { Selected ions } \\
\mathrm{m} / \mathrm{z}\end{array}$ & $\begin{array}{c}\text { RT } \\
\text { min }\end{array}$ & $\begin{array}{c}\text { Recovery } \\
\%\end{array}$ \\
\hline 1 & Naphthalene & Nap & 128 & $128,129,64$ & 5.69 & $82 \pm 2$ \\
2 & 2-Methylnaphthalene & 2-MNap & 142 & $142,143,71$ & 7.11 & $80 \pm 3$ \\
3 & Acenaphthylene & Acy & 152 & $152,153,76$ & 9.75 & $80 \pm 4$ \\
4 & Acenaphtene & Ace & 154 & $154,153,76$ & 10.44 & $86 \pm 3$ \\
5 & Fluorene & Fne & 166 & $166,165,82$ & 12.33 & $86 \pm 5$ \\
6 & Phenanthrene & Phe & 178 & $178,179,89$ & 16.21 & $82 \pm 6$ \\
7 & Anthracene & Ant & 178 & $178,179,89$ & 16.41 & $98 \pm 5$ \\
8 & Fluoranthene & Flt & 202 & $202,203,101$ & 21.52 & $77 \pm 6$ \\
9 & Pyrene & Pyr & 202 & $202,203,101$ & 22.45 & $72 \pm 4$ \\
10 & Benzo[a]anthracene & $\mathrm{B} a \mathrm{~A}$ & 228 & $226,229,114$ & 28.11 & $115 \pm 6$ \\
11 & Chrysene & $\mathrm{Chr}$ & 228 & $226,229,114$ & 28.28 & $97 \pm 3$ \\
12,13 & Benzo[b+k]fluoranthene & $\mathrm{B} b+k \mathrm{~F}$ & 252 & $252,253,126$ & 32.80 & $67 \pm 6$ \\
14 & Benzo[a]pyrene & $\mathrm{B} a \mathrm{P}$ & 252 & $252,253,126$ & 34.02 & $78 \pm 2$ \\
15 & Perylene & Per & 252 & $252,253,126$ & 34.36 & $80 \pm 6$ \\
16 & Indeno[1,2,3-cd]pyrene & $\mathrm{I} 123 c d \mathrm{P}$ & 276 & $276,277,138$ & 38.13 & $84 \pm 7$ \\
17 & Dibenzo[a,h]anthracene & $\mathrm{DB} a h \mathrm{~A}$ & 278 & $278,279,139$ & 38.33 & $107 \pm 3$ \\
18 & Benzo[ghi]perylene & $\mathrm{B} g h i \mathrm{P}$ & 276 & $276,277,138$ & 38.92 & $81 \pm 2$ \\
\hline
\end{tabular}

PAH: polycyclic aromatic hydrocarbon. 
from $67 \pm 6$ for $\mathrm{B} b+k \mathrm{~F}$ to $115 \pm 6$ for $\mathrm{B} a \mathrm{~A}$, which are according to TO-13A protocol (USEPA, 1999).

\subsection{Organic compound extractions}

Filters with particles were fortified with 11 deuterated PAHs (Table II) (98-99.9\% purity, Chem Service and Ultra Scientific, USA). The organic compounds were extracted ultrasonically (Branson 2510) with $10 \mathrm{~mL}$ of dichloromethane (HPLC grade, Burdick Jackson) according to the methodology published by Valle-Hernández et al. (2010).

\subsection{Analysis and quantification of polycyclic aro- matic hydrocarbons}

PAHs were identified and analyzed through GC/ MS (GC model HP 6890, MS model 5973, GCMS), with a $30 \mathrm{~m}, 0.25 \mathrm{~mm}$ diameter HP5 capillary column and $0.25 \mu \mathrm{m}$ thickness stationary phase. Ultrapure helium $(99.999 \%$, Praxair) with a $1.2 \mathrm{~mL} \mathrm{~min}^{-1}$ flow was the carrier gas. One $\mu \mathrm{L}$ was injected in splitless mode at $300{ }^{\circ} \mathrm{C}$. The applied temperature program started at $40{ }^{\circ} \mathrm{C}$ for 1 min, followed by a heating ramp of $50{ }^{\circ} \mathrm{C} \mathrm{min}^{-1}$ till $120^{\circ} \mathrm{C}$ remaining for 1 min during the first heating ramp; then $5^{\circ} \mathrm{C} \mathrm{min}{ }^{-1}$ till $305^{\circ} \mathrm{C}$ remaining for $1 \mathrm{~min}$ in the second ramp, and finally $20{ }^{\circ} \mathrm{C} \mathrm{min}-1$ till 330 ${ }^{\circ} \mathrm{C}$ during $10 \mathrm{~min}$. Operating conditions of GC-MS for PAHs analysis were previously stablished by Amador-Muñoz et al. (2011). Eighteen PAHs were quantified by isotopic dilution; those without their deuterated homologous were quantified with the immediate previous deuterated compound. Filter blanks were included and treated the same as the samples. The blanks' analysis indicated that no compound of interest was present.

\subsection{Toxic and mutagenic equivalence of PAHs}

Toxic equivalence factors (TEF) estimated by Nisbet and Lagoy (1992) and mutagenic equivalence factors (MEF) proposed by Durant et al. (1996) were multiplied by the obtained concentrations of each PAH in order to determine the toxic and mutagenic equivalences related to $\mathrm{B} a \mathrm{P}$ ( $\mathrm{B} a \mathrm{P}-\mathrm{TEQ}$ and $\mathrm{B} a \mathrm{P}-\mathrm{MEQ}$, respectively), which represent the carcinogenic and mutagenic potential or the airborne mixture.

\subsection{Statistical analyses}

STATISTICA v. 10 (Statsoft, OK, USA) software was used for statistical analyses. Non-parametric U-Mann-Whitney test was applied to compare medians of different measured parameters. Spearman coefficient was applied to assess the association between PAHs and particles, carbonaceous species, and some meteorological parameters like relative humidity, temperature and wind velocity.

\section{Results and discussion}

\subsection{Particle concentrations}

Figure 2 shows the variation of $\mathrm{PM}_{10}$ and $\mathrm{PM}_{2.5}$ concentrations during the two sampling periods (low activity [LA] and normal activity [NA]). Most weeks

Table II. Deuterated polycyclic aromatic hydrocarbons. Target and secondary ions.

\begin{tabular}{|c|c|c|c|c|c|c|}
\hline & PAH-d & ID & $\begin{array}{c}\text { Target ion } \\
\mathrm{m} / \mathrm{z}\end{array}$ & $\begin{array}{c}\text { Selected ions } \\
\mathrm{m} / \mathrm{z}\end{array}$ & $\begin{array}{l}\mathrm{RT} \\
\mathrm{min}\end{array}$ & $\begin{array}{l}\text { Added mass } \\
\text { ng }\end{array}$ \\
\hline 1 & Naphthalene- $\mathrm{d}_{8}$ & Nap-d 8 & 136 & $136,137,108$ & 5.61 & 75.0 \\
\hline 2 & Acenaphtene- $\mathrm{d}_{10}$ & Ace- $\mathrm{d}_{10}$ & 164 & $164,165,160$ & 10.35 & 75.2 \\
\hline 3 & Phenanthrene- $\mathrm{d}_{10}$ & Phe- $\mathrm{d}_{10}$ & 188 & $188,189,94$ & 16.15 & 75.2 \\
\hline 4 & Fluoranthene- $\mathrm{d}_{10}$ & Flt-d ${ }_{10}$ & 212 & $212,213,106$ & 21.45 & 75.0 \\
\hline 5 & Pyrene- $d_{10}$ & Pyr-d ${ }_{10}$ & 212 & $212,213,106$ & 22.39 & 75.0 \\
\hline 6 & Benzo $[a]$ anthracene- $\mathrm{d}_{12}$ & $\mathrm{~B} a \mathrm{~A}-\mathrm{d}_{12}$ & 240 & $240,241,120$ & 28.01 & 150.0 \\
\hline 7 & Chrysene- $\mathrm{d}_{12}$ & Chr-d 12 & 240 & $240,241,120$ & 28.17 & 75.2 \\
\hline 8 & Benzo $[b]$ fluoranthene- $\mathrm{d}_{12}$ & $\mathrm{~B} b \mathrm{~F}-\mathrm{d}_{12}$ & 264 & $264,265,132$ & 32.71 & 150.0 \\
\hline 9 & Benzo $[a]$ pyrene- $\mathrm{d}_{12}$ & $\mathrm{~B} a \mathrm{P}-\mathrm{d}_{12}$ & 264 & $264,265,132$ & 33.94 & 150.0 \\
\hline 10 & Perylene-d12 & Per- $d_{12}$ & 264 & $264,265,132$ & 34.27 & 75.2 \\
\hline 11 & Benzo $[g h i]$ perylene- $\mathrm{d}_{12}$ & BghiP-d 12 & 288 & $288,289,144$ & 38.85 & 150.0 \\
\hline
\end{tabular}

PAH-d: deuterated polycyclic aromatic hydrocarbon. 


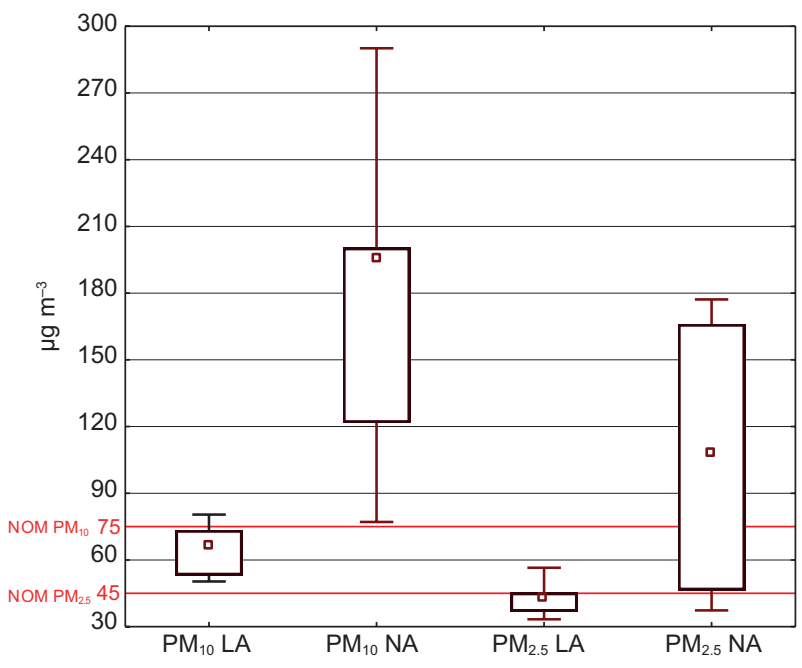

Fig. 2. $\mathrm{PM}_{10}$ and $\mathrm{PM}_{2.5}\left(\mu \mathrm{g} \mathrm{m}^{-3}\right)$. Boxes: 25 th-75th percentiles, bars: 10th-90th percentiles (medians). LA: low activity, NA: normal activity. Red lines correspond to Mexican standards.

in the year have normal activity, whereas low activity lasts only five weeks corresponding to vacation periods (Holly and Eastern weeks, Independence week in September, All Saints' Day in November, Christmas week and New Year week). The variation between both periods is due to the fact that artisan community operates in different modes: during NA artisans work daily, whereas during LA the kiln operations are carried out every three or four days. Medians and percentiles (10th and 90th) of $\mathrm{PM}_{10}$ concentrations were 66 (50-80) $\mathrm{g} \mathrm{g} \mathrm{m}^{-3}$ and 196 (77-290) $\mu \mathrm{g} \mathrm{m}^{-3}$ for LA and NA, respectively; and for $\mathrm{PM}_{2.5} 42$ (33-57) $\mu \mathrm{g} \mathrm{m}^{-3}$ and 108 (37-177) $\mu \mathrm{g} \mathrm{m}^{-3}$ for low and normal activity, respectively. During the first period of LA of adobe kilns, $\mathrm{PM}_{10}$ and $\mathrm{PM}_{2.5}$ concentrations were within the limits established by the Official Mexican Standard NOM-025-SSA1-2014 (SSA, 2014) of 75 and $45 \mu \mathrm{g} \mathrm{m}^{-3}$, respectively, but not the WHO standards of 50 and $25 \mathrm{\mu g} \mathrm{m}^{-3}$, respectively, which were exceeded all days. In the case of the second period of NA, the $\mathrm{PM}_{10}$ standard was exceeded all days, and the $\mathrm{PM}_{2.5}$ standard half of days; consequently, the WHO standards were exceeded all days in both sizes. Mexican Standard exceedances of PM concentrations were up to three times some days, and the medians exceeded the standards around twice, consequently having a high negative effect in the town air quality. Other researchers also observed that ceramic industry has a significant impact on air quality, due to the high emissions of atmospheric particles generated in combustion processes (Querol et al., 2001). In addition to the use of tires as fuel in the study area, particles emitted by the ceramic production also affect visibility, since during activity smoke columns are observed in the kilns. Other studies have reported high emissions due to tires burning, as was the case in Iowa, USA, where hundreds of shredded tires in a landfill burned uncontrollably increasing the ambient air $\mathrm{PM}_{2.5}$ concentrations to $70 \mu \mathrm{g} \mathrm{m}^{-3}$, although concentrations $1 \mathrm{~km}$ away from the sources were as high as $2 \mathrm{mg} \mathrm{m}^{-3}$ (Downard et al., 2015).

Significant differences $(p<0.05)$ were found between the median of particles in LA and NA periods. Figure 3 shows the wind roses of sampling days in the two periods of activity. It can be observed that although the winds come from several directions, the prevailing direction of winds was southwest, with speeds lower than $4 \mathrm{~m} \mathrm{~s}^{-1}$. These relatively low speeds can contribute to create a relative atmospheric stability and combined with low temperatures $\left(5-9{ }^{\circ} \mathrm{C}\right)$ the pollutant dispersion is minimum. Therefore, the difference in particle concentrations (both $\mathrm{PM}_{10}$ and $\mathrm{PM}_{2.5}$ ) is due to the number of kilns operating in each activity period, and not to the climatic conditions, since no correlations were observed between particles and temperature or wind speed $(p>0.05)$.

Significant differences were only observed between $\mathrm{PM}_{10}$ and $\mathrm{PM}_{2.5}$ concentrations during the LA period $(p<0.05)$, since other sources such as dust resuspension or vehicles can contribute to $\mathrm{PM}_{10}$ presence. In opposite, during the NA period no significant differences were found between $\mathrm{PM}_{10}$ and $\mathrm{PM}_{2.5}$ concentrations ( $\mathrm{p}>0.05$ ), thus suggesting the same origin source for both particle sizes related to the combustion of tires $\left(\mathrm{PM}_{2.5}\right)$ in adobe kilns, which increased significantly during this period since there is no other significant combustion source in the studied area.

\subsection{Carbonaceous species concentrations}

Table III displays the descriptive statistics of PM, organic and elemental carbon concentrations, as well as those of quantified PAHs. OC was a major 


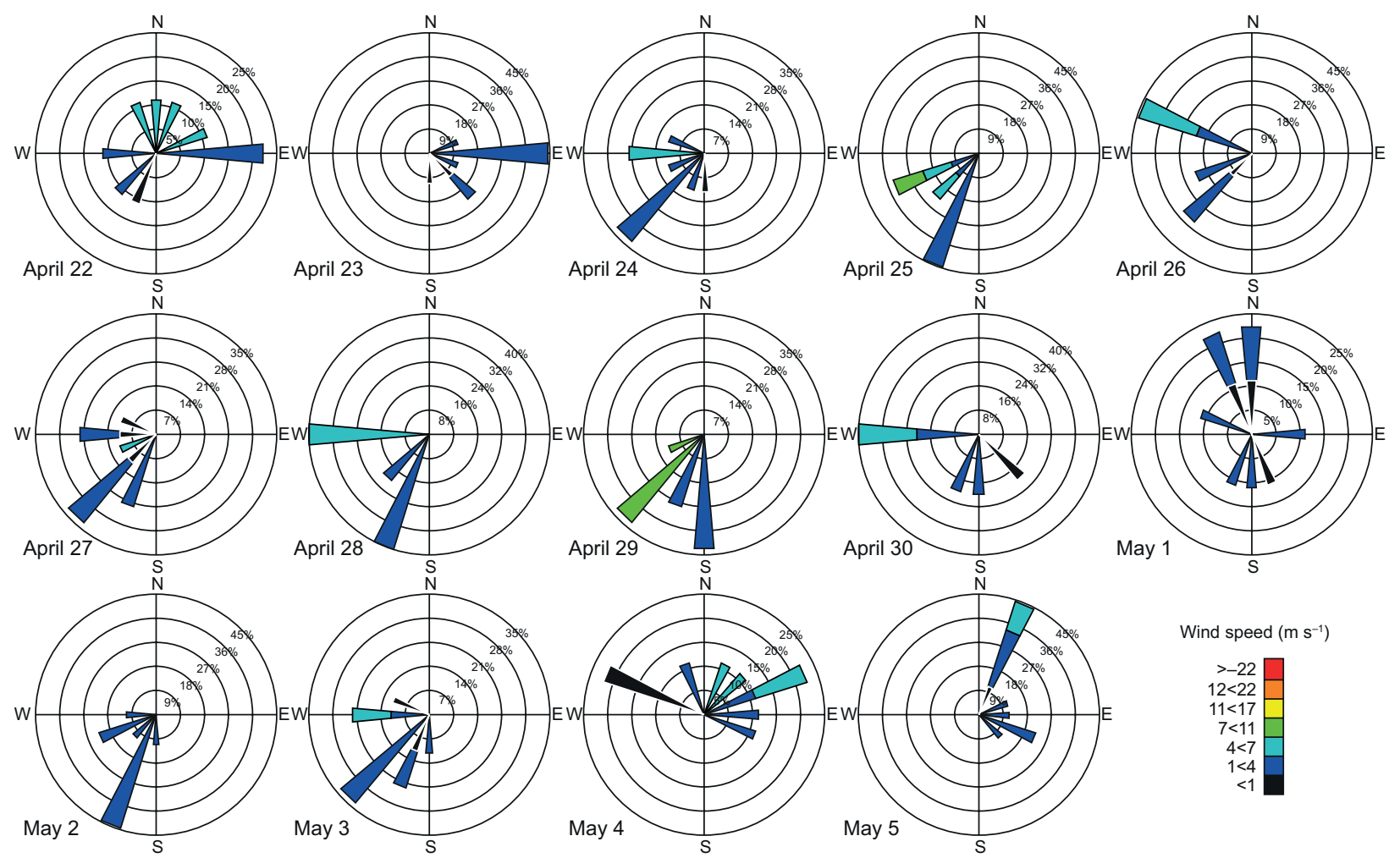

Fig. 3. Wind roses during the sampling period.

component of both PM sizes, accounting for 34\% (31-35\%) and 47\% (37-52\%) of $\mathrm{PM}_{10}$ during low and normal activity of adobe kilns, respective$1 \mathrm{y}$, and for $42 \%(31-52 \%)$ and $54 \%(52-61 \%)$ of $\mathrm{PM}_{2.5}$, for the same periods. These contributions are within the $22-58 \%$ range reported by Chow et al. (2011) for OC emissions from burned tires. The OC contribution to the total mass of particles was lower during the artisans' low activity period than during the normal activity period, suggesting that in the latter the combustion source becomes most important. Indeed, these results are of concern since the toxicity of carbonaceous particles is more clearly associated to the organic fraction than to the elemental one (Kocbach et al., 2006). Nevertheless, OC concentrations of $\mathrm{PM}_{10}$ and $\mathrm{PM}_{2.5}$ had no significant differences between them $(\mathrm{p}>0.05)$ in any activity period.

This behavior was also observed for EC concentrations that did not present significant differences ( $\mathrm{p}>0.05$ ) between $\mathrm{PM}_{10}$ and $\mathrm{PM}_{2.5}$ in both activity periods, indicating that $\mathrm{OC}$ and $\mathrm{EC}$ are mainly in the fine fraction. EC contributed from 8-18 and 12-36\% of $\mathrm{PM}_{10}$ and $\mathrm{PM}_{2.5}$, respectively, during low and normal activity periods. EC percentages were lower than the $29-61 \%$ reported by Chow et al. (2011) for $\mathrm{PM}_{2.5}$ from tires burning, but greater than the $8 \%$ reported by Downard et al. (2015). This can be explained by different combustion conditions, since higher temperatures are reached during more time in adobe kilns than during an uncontrolled fire.

\subsection{Polycyclic aromatic hydrocarbon concentra- tions}

No significant differences were found between PAHs in $\mathrm{PM}_{10}$ and $\mathrm{PM}_{2.5}(\mathrm{p}>0.05)$, meaning that PAHs from combustion sources are majorly found in the fine fraction. As can be observed in Table III, PAHs are largely in the fine fraction, 90\% during LA and $70 \%$ during NA. Heavier PAHs concentrations (> $206 \mathrm{~g} \mathrm{~mol}^{-1}$ ) in the two PM sizes were around twice during NA than in LA. Among the PAHs of special concern are those classified as carcinogenic by the International Agency for Research on Cancer (IARC) 
Table III. Descriptive statistics of PM, OC, EC and PAHs.

\begin{tabular}{|c|c|c|c|c|c|c|c|c|c|c|c|c|c|c|c|c|}
\hline & \multicolumn{8}{|c|}{$\mathrm{PM}_{10}$} & \multicolumn{8}{|c|}{$\mathrm{PM}_{2.5}$} \\
\hline & \multicolumn{4}{|c|}{ Low activity } & \multicolumn{4}{|c|}{ Normal activity } & \multicolumn{4}{|c|}{ Low activity } & \multicolumn{4}{|c|}{ Normal activity } \\
\hline & $\mathrm{N}$ & Median & P10 & P90 & $\mathrm{N}$ & Median & $\mathrm{P} 10$ & P90 & $\mathrm{N}$ & Median & P10 & P90 & $\mathrm{N}$ & Median & $\mathrm{P} 10$ & P90 \\
\hline \multicolumn{17}{|l|}{$\mu \mathrm{g} \mathrm{m}^{-3}$} \\
\hline PM & 7 & 66.2 & 50.4 & 80.4 & 6 & 195.9 & 77.1 & 290.1 & 7 & 42.4 & 33.3 & 56.5 & 6 & 107.8 & 37.3 & 177.1 \\
\hline $\mathrm{OC}$ & 7 & 22.5 & 13.8 & 27.4 & 6 & 87.8 & 36.0 & 93.2 & 7 & 17.7 & 10.5 & 23.6 & 6 & 62.9 & 20.2 & 90.0 \\
\hline $\begin{array}{l}\mathrm{EC} \\
\mathrm{ng} \mathrm{m}^{-3}\end{array}$ & 7 & 5.0 & 4.0 & 6.1 & 6 & 34.0 & 14.1 & 80.4 & 7 & 5.3 & 0.9 & 10.6 & 6 & 35.7 & 13.3 & 64.5 \\
\hline Nap & 7 & 0.8 & 0.3 & 1.8 & 6 & 0.9 & 0.4 & 1.6 & 7 & 0.5 & 0.2 & 1.1 & 6 & 0.7 & 0.3 & 1.0 \\
\hline 2-MNap & 6 & 0.2 & 0.1 & 0.4 & ( & 0.2 & 0.1 & 0.5 & 7 & 0.2 & 0.1 & 0.4 & 6 & 0.2 & 0.1 & 0.4 \\
\hline Acy & 7 & 0.2 & 0.1 & 0.3 & ( & 0.2 & 0.2 & 0.8 & 7 & 0.2 & 0.0 & 0.2 & 5 & 0.2 & 0.1 & 0.3 \\
\hline Fne & 7 & 0.2 & 0.1 & 0.4 & 6 & 0.2 & 0.1 & 0.7 & 7 & 0.1 & 0.0 & 0.2 & 5 & 0.2 & 0.1 & 0.4 \\
\hline Phe & 7 & 2.2 & 1.7 & 4.2 & 6 & 3.5 & 2.9 & 15.8 & 7 & 1.6 & 0.7 & 3.3 & 6 & 2.9 & 1.3 & 15.0 \\
\hline Ant & 7 & 0.2 & 0.0 & 0.6 & 6 & 0.4 & 0.2 & 2.4 & 6 & 0.2 & 0.1 & 0.4 & 6 & 0.4 & 0.2 & 1.3 \\
\hline Flt & 7 & 8.4 & 4.3 & 13.6 & 6 & 16.4 & 11.9 & 59.8 & 7 & 6.4 & 2.5 & 11.2 & 6 & 13.1 & 6.3 & 28.9 \\
\hline Pyr & 7 & 7.7 & 3.3 & 14.1 & 6 & 17.9 & 8.4 & 62.6 & 7 & 7.1 & 2.2 & 10.7 & 6 & 13.5 & 6.3 & 30.2 \\
\hline Ret & 6 & 0.5 & 0.1 & 0.7 & 6 & 0.4 & 0.1 & 1.1 & 6 & 0.3 & 0.1 & 1.1 & 6 & 0.2 & 0.0 & 0.4 \\
\hline $\mathrm{B} a \mathrm{~A}$ & 7 & 3.2 & 0.6 & 4.8 & 6 & 7.2 & 4.6 & 23.7 & 7 & 2.0 & 1.2 & 3.9 & 6 & 5.3 & 2.9 & 11.4 \\
\hline Chr & 7 & 3.9 & 1.5 & 6.9 & 6 & 9.8 & 6.6 & 34.0 & 7 & 3.3 & 2.3 & 5.4 & 6 & 7.1 & 4.3 & 15.7 \\
\hline $\mathrm{B} b+k \mathrm{~F}$ & 7 & 11.3 & 6.3 & 14.1 & 6 & 23.5 & 14.2 & 61.7 & 7 & 9.0 & 6.7 & 11.3 & 6 & 16.3 & 10.9 & 29.6 \\
\hline $\mathrm{B} a \mathrm{P}$ & 7 & 6.5 & 3.1 & 11.4 & 6 & 15.9 & 10.4 & 59.1 & 7 & 6.0 & 3.0 & 10.7 & 6 & 12.2 & 9.1 & 23.4 \\
\hline $\mathrm{I} 123 c d \mathrm{P}$ & 7 & 12.8 & 3.9 & 17.2 & 6 & 29.0 & 19.6 & 80.0 & 7 & 13.8 & 6.1 & 16.6 & 6 & 14.8 & 9.6 & 37.1 \\
\hline $\mathrm{DB} a h \mathrm{~A}$ & 6 & 1.6 & 0.6 & 1.9 & 6 & 3.1 & 0.8 & 10.3 & 6 & 1.7 & 0.4 & 2.4 & 5 & 2.6 & 0.4 & 4.2 \\
\hline BghiP & 7 & 8.9 & 4.6 & 11.2 & 6 & 16.8 & 10.6 & 46.3 & 7 & 7.5 & 3.8 & 9.4 & 6 & 11.5 & 8.8 & 21.6 \\
\hline$\sum \mathrm{PAH}_{\text {carc }}$. & 7 & 35.4 & 19.5 & 55.9 & 6 & 91.8 & 56.7 & 268.8 & 7 & 36.2 & 19.3 & 48.1 & 6 & 62.4 & 38.3 & 121.4 \\
\hline$\sum \mathrm{PAH}_{\text {tot. }}$ & 7 & 67.1 & 37.4 & 99.7 & 6 & 157.6 & 96.9 & 459.7 & 7 & 61.0 & 29.0 & 79.8 & 6 & 110.4 & 63.2 & 211.1 \\
\hline
\end{tabular}

PM: particulate matter; OC: carbonaceous fraction of PM; EC: elemental carbon; PAHs: polycyclic aromatic hydrocarbons.

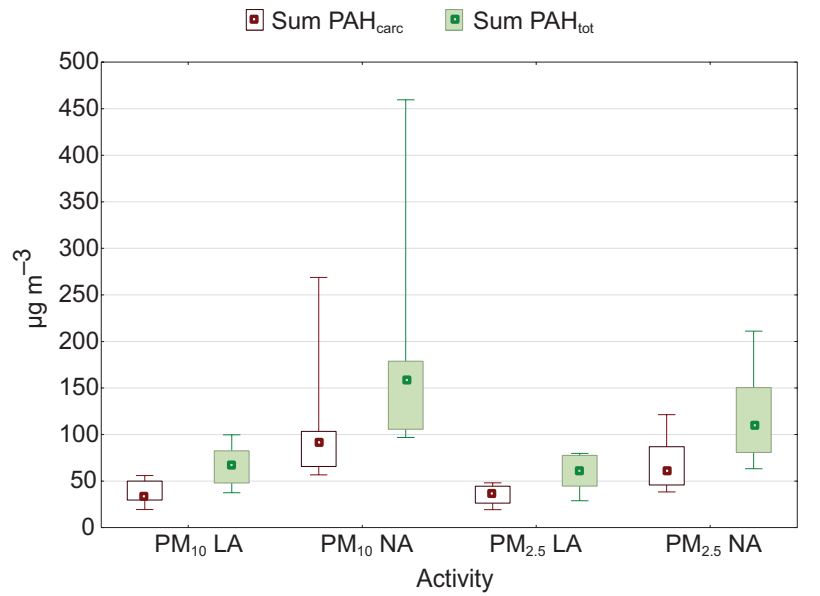

Fig. 4. Medians of the sum of total PAHs $\left(\mathrm{PAH}_{\mathrm{tot}}\right)$ and carcinogenic PAHs $\left(\mathrm{PAH}_{\text {carc }}\right)$. Boxes: 25th-75th percentiles; bars: 10th-90th percentiles. LA: low activity, NA: normal activity. $\Sigma \mathrm{PAH}_{\text {carcinogenic: }} \mathrm{B} a \mathrm{~A}, \mathrm{Chr}, \mathrm{B} b+k \mathrm{~F}, \mathrm{~B} a \mathrm{P}$, $\mathrm{I} 123 c d \mathrm{P}$ and $\mathrm{DB} a h \mathrm{~A}$. 
(BaA, Chr, Bb+kF, BaP, I123cdP, and DBahA), which correspond to those with higher molecular weight (except for $\mathrm{BghiP}$ ); Figure 4 presents the comparison of the sum of total PAHs with the sum of carcinogenic PAHs in $\mathrm{PM}_{10}$ and $\mathrm{PM}_{2.5}$ during both activity periods. Carcinogenic PAHs accounted for 53 and $58 \%$ of the total PAHs in $\mathrm{PM}_{10}$ through the low and normal adobe kiln activity periods, respectively, whereas carcinogenic PAHs contributed with 59 and $57 \%$ of the total sum of PAHs in $\mathrm{PM}_{2.5}$ in the same periods. These carcinogenic PAHs have also been determined in studies related to tires burning, contributing with more than $50 \%$ of the total analyzed PAHs (Lemieux et al., 2004; Lönnermark and Blomqvist, 2005). However, most of three-ring PAHs can occur in the gaseous phase, so that their concentrations associated with PM should be compared carefully.

Naphthalene was the most abundant PAH within the lighter compounds (two and three rings), whereas fluoranthene and pyrene, having four rings, were the most abundant non mutagenic PAHs. Carcinogenic

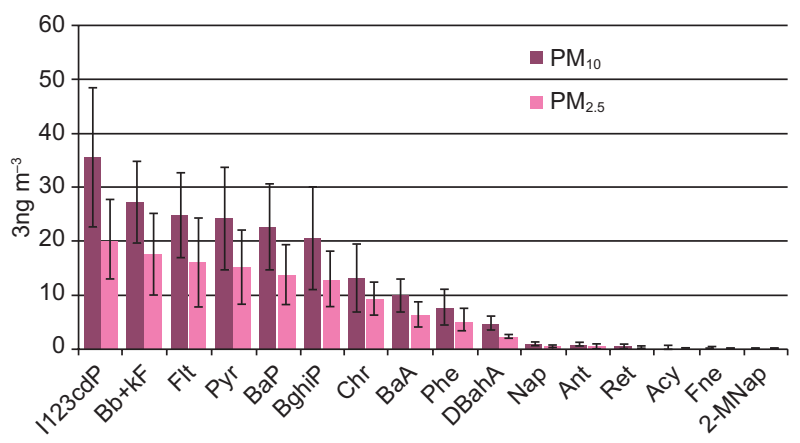

Fig. 5. Average PAHs abundance and standard deviations in $\mathrm{PM}_{10}$ and $\mathrm{PM}_{2.5}$ during normal activity of adobe kilns.

PAHs $\mathrm{I} 123 c d \mathrm{P}, \mathrm{B} b+k \mathrm{~F}$, and $\mathrm{B} a \mathrm{P}$, presented the greater concentrations during the normal activity of adobe kilns as shown in Figure 5.

The high concentrations of carcinogenic compounds represent an important risk for population, since the median concentrations in this study are more than 10 times higher than those medians reported in Mexico City (Amador-Muñoz et al., 2009; Mugica et al., 2010), as well as those reported during sugarcane harvesting in the state of Morelos (Mugica-Álvarez et al., 2015); for instance, $\mathrm{B} a \mathrm{P}$ concentrations in $\mathrm{PM}_{10}$ in Mexico City and Morelos were $0.5 \mathrm{ng} \mathrm{m}^{-3}$, while in the present study they were $9.5 \mathrm{ng} \mathrm{m}^{-3}$. In addition, as was mentioned above, more PAHs in the fine fraction can penetrate into the deepest part of the lungs and even enter the bloodstream through the alveoli, causing a deeper damage (Pope and Dockery, 2006). Santiago Coachochitlán has some low elevations of volcanic relief with moderate slopes and some hills, so particulate matter and PAH concentrations may even be greater in the cold dry season when temperatures are lower at dawn by possible thermal inversions or stable conditions. Hence, PM monitoring would be convenient during that season to determine the population exposure (IPOMEX, 2015).

\subsection{PAHs diagnostic ratios}

Several researchers have estimated diagnostic ratios for some PAHs emission sources (Grimmer et al., 1983; Sicre et al., 1987; Khalili et al., 1995; Pandey et al., 1999; Ravindra et al., 2006; Rajput et al., 2011; Li et al., 2016). Table IV presents some of those ratios as well as the obtained ratios in this study, where it is possible to observe that no source reported previously corresponds to the PAH ratios found on the site.

The means of obtained PAHs ratios of $\mathrm{PM}_{10}$ and $\mathrm{PM}_{2.5}$ from tires combustion emission during the two activity periods were not meaningfully different $(\mathrm{p}>$ $0.05)$, indicating that it could be adequate to diagnose the contribution of tires combustion sources in adobe kilns (Table IV), since there are no other significant emission sources in the site. However, some of the obtained ratios showed high standard deviations ( $>$ $20 \%$ ), since certain PAHs can be unstable and reactive, indicating that some ratios are not robust enough to be considered as good markers for tire combustion.

Table $\mathrm{V}$ displays the diagnostic ratios that presented relative standard deviation (RSD) less than 15\%, by activity period and particle size. PAHs ratios are useful to differentiate petrogenic or pyrogenic PAHs. Petrogenic are associated usually to PAHs such as Nap, Flu, Phe and Cry, whereas pyrogenic PAHs are dominated by unsubstituted high molecular weight PAHs with abundant Flt and Pyr (Wang et al., 2007; González-Sepúlveda et al., 2013). [Flt $] /([\mathrm{Pyr}]+[$ Flt $])$ ratio $>0.5$ indicate pyrogenic sources although ratios $<0.5$ have been found for vehicular emissions, while $[\mathrm{I} 123 \mathrm{cdP}] /([\mathrm{I} 123 \mathrm{cdP}]+[\mathrm{BghiP}])$ ratios with values 

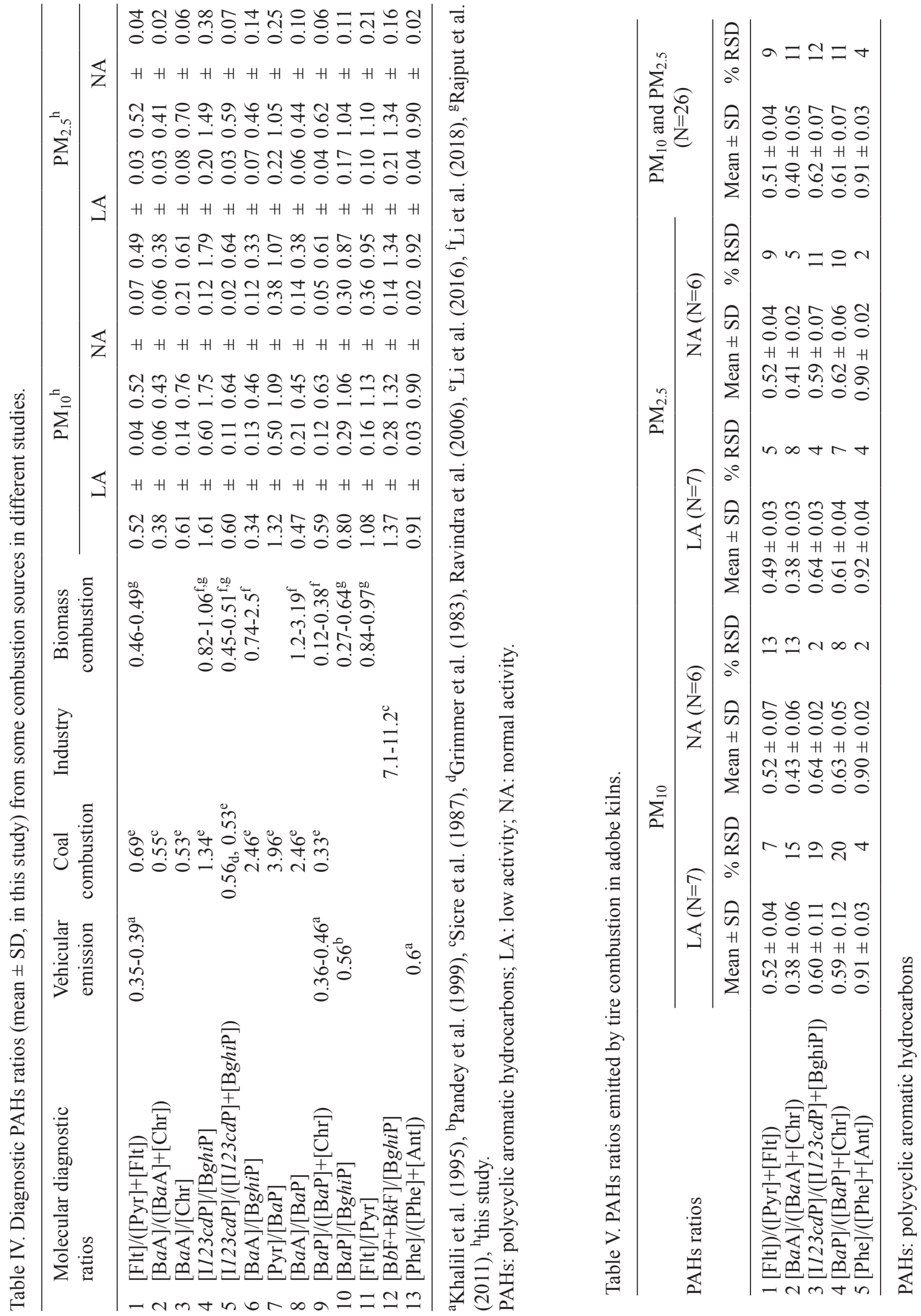
between $(0.20-0.50)$ correlate mostly with petrogenic origin (i.e., unburned or leaked fuel and oil, road asphalt, and tire particles), but $[\mathrm{BaA}] /([\mathrm{BaA}]+[\mathrm{Chr}])$ $>0.35$ is attributed to pyrogenic sources (Nguyen et al., 2014); additionally, the high content of unsubstituted high molecular weight PAHs corroborates that pyrogenic emissions were dominant in this study (Mille et al., 2007).

When ratios of the two particle sizes are included (since there were not significant differences, $\mathrm{p}>$ $0.05)$, RSD is $\leq 10 \%$, they can be considered robust rates and proposed as new diagnostic PAHs rates for tire combustion emissions, which is the main combustion source (last column in Table V).

\subsection{Carcinogenic and mutagenic potential}

The carcinogenic potential or PAHs toxicity mixture can be expressed as the toxic equivalence (TEQ) through the use of toxic equivalence factors (TEF) that express the toxicity of each PAH in terms of the most toxic form of these compounds, the $\mathrm{B} a \mathrm{P}$ (Nisbet and Lagoy, 1992). In the estimation of mutagenic potential, mutagenic equivalence factors (MEF) were used (Durant et al., 1996). Table VI displays the TEQ and MEQ of the quantified PAHs in particles of both sizes and sampling periods. The greatest contribution to $\mathrm{B} a \mathrm{P}-\mathrm{TEQ}$ and $\mathrm{B} a \mathrm{P}-\mathrm{MEQ}$ was in all cases $\mathrm{B} a \mathrm{P}$ with $15.9 \mathrm{ng} \mathrm{m}^{-3}$ for $\mathrm{PM}_{10}$ and $12.2 \mathrm{ng} \mathrm{m}^{-3}$ for $\mathrm{PM}_{2.5}$ during NA, contributing with 63 and $65 \%$ to $\mathrm{B} a \mathrm{P}-\mathrm{TEQ}$ of $\mathrm{PM}_{10}$ and $\mathrm{PM}_{2.5}$, respectively, and with 54 and $60 \%$ to $\mathrm{B} a \mathrm{P}-\mathrm{MEQ}$ of $\mathrm{PM}_{10}$ and $\mathrm{PM}_{2.5}$, respectively. The European Parliament and the Council of the European Union (DIRECTIVE 2004/107/EC) set a BaP-TEQ maximum value of $1 \mathrm{ng} \mathrm{m}^{-3}$ in $\mathrm{PM}_{10}$ as annual average to reduce the population risk, whereas the recommended value in the United Kingdom is $0.25 \mathrm{ng} \mathrm{m}^{-3}$ in $\mathrm{PM}_{10}$. It is concerning to observe that PAHs concentrations are high even during the LA of kilns and consequently carcinogenic and mutagenic potency are also high, suggesting that PAHs remain in fine particles in the atmosphere. Certainly, it should be a matter of earnest directives that in this town the standard is exceeded more than 25 times during the NA period and more than 10 times during LA activity of adobe kilns.

Table VI. Carcinogenic and mutagenic potentials (BaP-TEQ and BaP-MEQ) estimated from the medians of PAHs in $\mathrm{PM}_{10}$ and $\mathrm{PM}_{2.5}$.

\begin{tabular}{|c|c|c|c|c|c|c|c|c|c|c|c|}
\hline & \multirow{3}{*}{ PAH } & \multirow{3}{*}{ TEF } & \multirow{3}{*}{ MEF } & \multicolumn{4}{|c|}{$\mathrm{B} a \mathrm{P}-\mathrm{TEQ}\left[\mathrm{ng} \mathrm{m}^{-3}\right]$} & \multicolumn{4}{|c|}{$\mathrm{B} a \mathrm{P}-\mathrm{MEQ}\left[\mathrm{ng} \mathrm{m}^{-3}\right]$} \\
\hline & & & & \multicolumn{2}{|c|}{$\mathrm{PM}_{10}$} & \multicolumn{2}{|c|}{$\mathrm{PM}_{2.5}$} & \multicolumn{2}{|c|}{$\mathrm{PM}_{10}$} & \multicolumn{2}{|c|}{$\mathrm{PM}_{2.5}$} \\
\hline & & & & Low & Normal & Low & Normal & Low & Normal & Low & Normal \\
\hline 1 & Nap & 0.001 & NR & 0.0008 & 0.0009 & 0.0005 & 0.0007 & NR & NR & NR & NR \\
\hline 2 & Acy & 0.001 & 0.0006 & 0.0002 & 0.0002 & 0.0002 & 0.0002 & 0.0001 & 0.0001 & 0.0001 & 0.0001 \\
\hline 3 & Fne & 0.001 & NR & 0.0002 & 0.0002 & 0.0001 & 0.0002 & NR & NR & NR & NR \\
\hline 4 & Phe & 0.001 & NR & 0.0022 & 0.0035 & 0.0016 & 0.0029 & NR & NR & NR & NR \\
\hline 5 & Ant & 0.01 & NR & 0.0020 & 0.0040 & 0.0020 & 0.0040 & NR & NR & NR & NR \\
\hline 6 & Flt & 0.001 & NR & 0.0084 & 0.0164 & 0.0064 & 0.0131 & NR & NR & NR & NR \\
\hline 7 & Pyr & 0.001 & NR & 0.0077 & 0.0179 & 0.0071 & 0.0135 & NR & NR & NR & NR \\
\hline 8 & $\mathrm{~B} a \mathrm{~A}$ & 0.1 & 0.082 & 0.3200 & 0.7200 & 0.2000 & 0.5300 & 0.2624 & 0.5904 & 0.1640 & 0.4346 \\
\hline 9 & $\mathrm{Chr}$ & 0.01 & 0.017 & 0.0390 & 0.0980 & 0.0330 & 0.0710 & 0.0663 & 0.1666 & 0.0561 & 0.1207 \\
\hline 10 & $\mathrm{~B} b+k \mathrm{~F}$ & 0.1 & NR & 1.1300 & 2.3500 & 0.9000 & 1.6300 & NR & NR & NR & NR \\
\hline 13 & $\mathrm{~B} a \mathrm{P}$ & 1 & 1 & 6.5000 & 15.9000 & 6.0000 & 12.2000 & 6.5000 & 15.9000 & 6.0000 & 12.2000 \\
\hline 14 & $\mathrm{DB} a h \mathrm{~A}$ & 1 & 0.29 & 1.6000 & 3.1000 & 1.7000 & 2.6000 & 0.4640 & 0.8990 & 0.4930 & 0.7540 \\
\hline 16 & $\mathrm{I} 123 c d \mathrm{P}$ & 0.1 & 0.31 & 1.2800 & 2.9000 & 1.3800 & 1.4800 & 3.9680 & 8.9900 & 4.2780 & 4.5880 \\
\hline 17 & BghiP & 0.01 & 0.19 & 0.0890 & 0.1680 & 0.0750 & 0.1150 & 1.6910 & 3.1920 & 1.4250 & 2.1850 \\
\hline \multicolumn{4}{|c|}{ Total $\mathrm{B} a \mathrm{P}-\mathrm{TEQ}$ and $\mathrm{B} a \mathrm{P}-\mathrm{MEQ}$} & 10.980 & 25.279 & 10.306 & 18.661 & 12.952 & 29.738 & 12.416 & 20.282 \\
\hline
\end{tabular}

TEF: toxic equivalence factor (Nisbet and Lagoy, 1992); MEF: mutagenic equivalence factor (Durant et al., 1996). 
The high $\mathrm{B} a \mathrm{P}-\mathrm{TEQ}$ estimated values from 11 to $25 \mathrm{ng} \mathrm{m}^{-3}$ indicate that particles emitted during tires burning in adobe kilns could be highly hazardous as was reported by Lemieux et al. (2004), who found that the uncontrolled burning of tires results in extremely high mutagenic particle emissions, representing a high risk for the population. The $\mathrm{B} a \mathrm{P}-\mathrm{TEQ}$ of this study are from 10 to 50 times higher than those reported for $\mathrm{PM}_{10}$ in sites with frequent agricultural burning (Mugica-Alvarez et al., 2015; Pongpiachan et al., 2017), and are greater than those reported for $\mathrm{PM}_{10}$ in sites with high vehicular traffic such as Florence and Venice, Italy, with annual means of 2.6 and $1.9 \mathrm{ng} \mathrm{m}^{-3}$, respectively (Masiol et al., 2012), Augsburg, Germany with $3.27 \mathrm{ng} \mathrm{m}^{-3}$ (Schnelle et al., 2005), and Copenhagen, Denmark with $6.9 \mathrm{ng} \mathrm{m}^{-3}$, and only comparable with Guangzhou city in China, which reported $\mathrm{B} a \mathrm{P}-\mathrm{TEQ}$ s up to $25.44 \mathrm{ng} \mathrm{m}^{-3}$ (Bi et al., 2005).

The presence of extremely high mutagenic and carcinogenic compounds in particles shows that inhabitants of this little town are in high risk due to exposure of multiple emissions from scrap tires burning in adobe kilns. Therefore, the most important strategy to achieve reductions would be to replace to less pollutant fuels, or changes in oven technology such as the inclusion of high temperature ceramic filters which have shown reduction of particles and PAHs among 60 to $90 \%$ (Caponero et al., 2004)in the form of waste tire chips $(1 \mathrm{~cm}$ in size. This is a complex issue since cultural and economic facets at local level make very difficult implementation of any change; so, education programs would be necessary to explain people the benefits in health and quality life of modifications in their habits and in ancestral ovens.

\subsection{Relationships between species}

Table VII displays the Spearman correlation between PM, carbonaceous species and individual PAHs. OC and EC have high correlations with PM, as well as with most PAHs with higher molecular weight; exceptions are the lighter PAHs of two and three rings (Nap, 2-MNap, Acy, Fne, and Ant). The meaningful correlation between PM and individual PAHs with equal or more than four rings suggests that their emitting sources could be the same, namely, more than 400 clay ovens in the area. The relationships between meteorological parameters (wind speed, temperature, and relative humidity) and measured pollutants did not show statistically significant correlation $(p>0.05)$.

\section{Conclusions}

$\mathrm{PM}_{2.5}$ and $\mathrm{PM}_{10}$ emissions from burning scrap tires used as fuel in adobe ovens in Santiago Coachotitlán exceeded the Mexican Standards of air quality most days and all days, respectively, during NA, whereas the WHO standard was exceeded all days even during LA. The exceedances of these standards implicate health risks for the population.

The most abundant species was OC, which accounted for $82 \%$ of $\mathrm{PM}_{2.5}$ during the NA period. PAHs are present this fraction, being $\mathrm{I} 123 c d \mathrm{P}, \mathrm{B} b+k \mathrm{~F}$, and $\mathrm{B} a \mathrm{P}$ the most abundant carcinogenic species. Carcinogenic PAHs accounted for 53 to $59 \%$ of total PAHs considering both sizes and activity periods.

The carcinogenic and mutagenic potentials of PAHs ( $\mathrm{B} a \mathrm{P}-\mathrm{TEQ}$ and $\mathrm{B} a \mathrm{P}-\mathrm{MEQ}$ ) were more than 10 times higher during the LA period and more than 25 times higher during the NA period than the recommended values by the European Commission, representing a very important risk for the population, which is exposed to these pollutants every day. Those values are higher than the reported in cities and megacities with high vehicle traffic.

The diagnostic ratios $[\mathrm{Flt}] /([\mathrm{Pyr}]+[\mathrm{Flt}])$ and $[\mathrm{BaA}] /([\mathrm{BaA}]+[\mathrm{Chr}])$, as well as the dominance of high molecular weight PAHs confirmed the dominance of pyrolytic PAHs. Mmoreover, some diagnostic ratios for scrap tires combustion were proposed for $\mathrm{PM}_{10}$ and $\mathrm{PM}_{2.5}$, which can be used with ratios previously published for sources identification.

The intervention of authorities to mitigate these highly toxic pollutant levels is urgent. Nevertheless, sociocultural and economic issues should be taken into account to implement educational programs in order to convince artisans of the need to avoid the burning of scrap tires and consider changes to the ancestral technology of adobe ovens, such as the inclusion of particle filters.

\section{Acknowledgments}

Authors are grateful to CONACYT for its support through Infrastructure Project number 271115. 


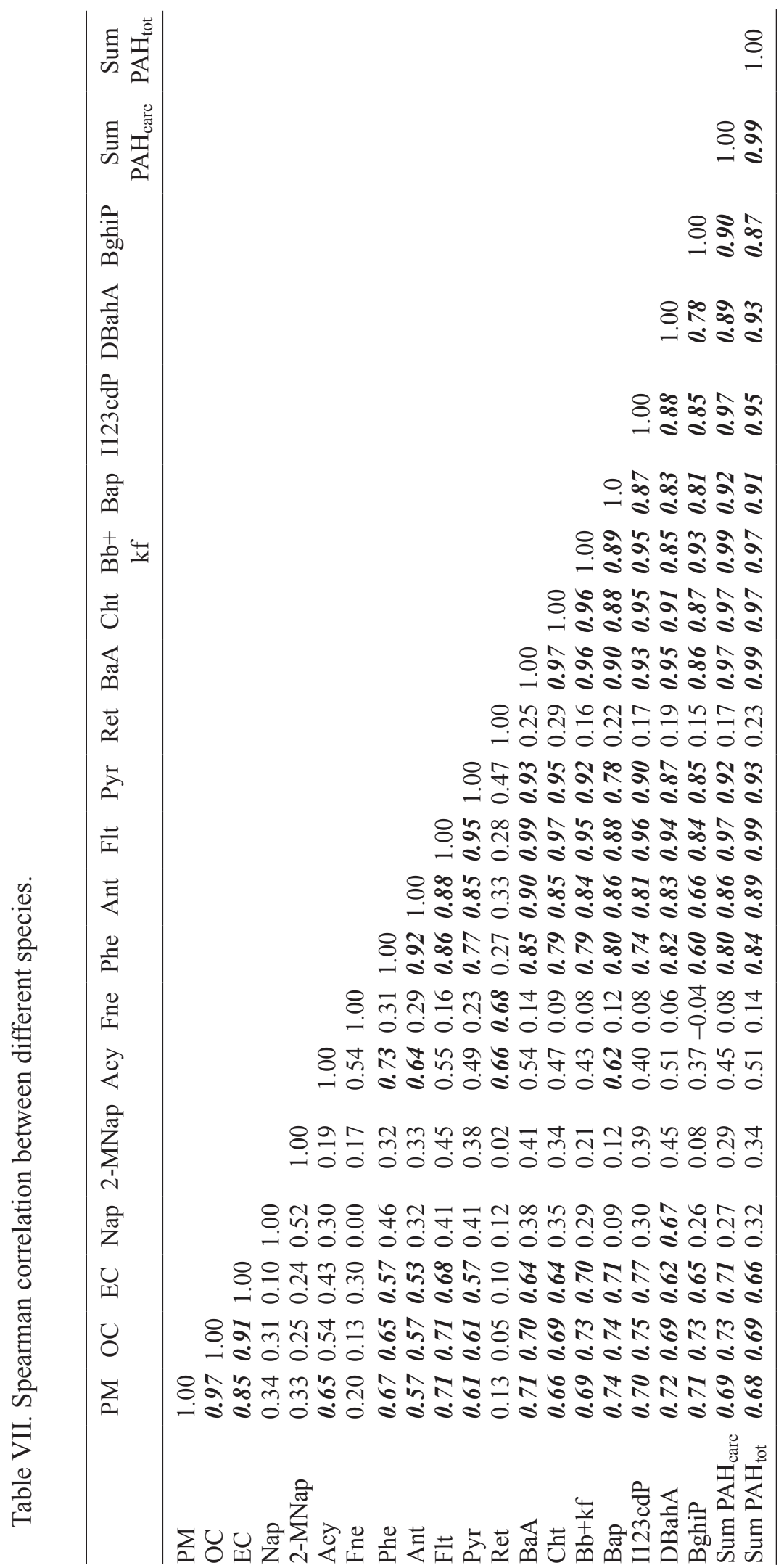




\section{References}

Alvarado-Cruz I, Sánchez-Guerra M, Hernández-Cadena L, De Vizcaya-Ruiz A, Mugica V, Pelallo-Martínez NA, et al. 2017. Increased methylation of repetitive elements and DNA repair genes is associated with higher DNA oxidation in children in an urbanized, industrial environment. Mutation Research/Genetic Toxicology and Environmental Mutagenesis 813, 27-36. https:// doi.org/10.1016/j.mrgentox.2016.11.007

Amador-Muñoz O, Villalobos-Pietrini R, Agapito-Nadales MC, Munive-Colín Z, Hernández-Mena L, Sánchez-Sandoval M, et al. 2009. Solvent extracted organic matter and polycyclic aromatic hydrocarbons distributed in size-segregated airborne particles in a zone of México City: Seasonal behavior and human exposure. Atmospheric Environment 44, 122-130. https://doi.org/10.1016/j.atmosenv.2009.07.012

Amador-Muñoz O, Villalobos-Pietrini R, Miranda J, Vera-Ávila LE. 2011. Organic compounds of PM2.5 in Mexico Valley: Spatial and temporal patterns, behavior and sources. Science of the Total Environment 409, 1453-1465. https://doi.org/10.1016/j. scitotenv.2010.11.026

Amador-Muñoz O, Bazán-Torija S, Villa-Ferreira SA, Villalobos-Pietrini R, Bravo-Cabrera JL, Munive-Colín Z, et al. 2013. Opposing seasonal trends for polycyclic aromatic hydrocarbons and PM10: Health risk and sources in southwest Mexico City. Atmospheric Research 122, 199-212. https://doi.org/10.1016/j. atmosres.2012.10.003

Ames M, Zemba S, Green L, Botelho MJ, Gossman D, Linkov I, et al. 2012. Polychlorinated dibenzo(p) dioxin and furan (PCDD/F) congener profiles in cement kiln emissions and impacts. Science of the Total Environment 419, 37-43. https://doi.org/10.1016/j. scitotenv.2011.12.062

Atal A, Levends YA, Carlson J, Dunayevskiy Y, Vouros P. 1997. On the survivability and pyrosynthesis of PAH during combustion of pulverized coal and tire crumb. Combustion and Flame 110, 462-478. https:// doi.org/10.1016/S0010-2180(97)00086-2

Aztatzi-Aguilar OG, Valdés-Arzate A, Debray-García Y, Calderón-Aranda ES, Uribe-Ramírez M, Acosta-Saavedra L, et al. 2018. Exposure to ambient particulate matter induces oxidative stress in lung and aorta in a size- and time-dependent manner in rats. Toxicology Research and Application 2, 1-15. https:// doi.org/10.1177/2397847318794859
Barlaz MA, Eleazer WE, Whittle DJ. 1993. Potential to use waste tires as supplemental fuel in pulp and paper mill boilers, cement kilns and in road pavement. Waste Management \& Research 11, 463-480. https://doi. org/10.1006/wmre.1993.1050

Bi X, Sheng G, Peng P, Chen Y, Fu J. 2005. Size distribution of n-alkanes and polycyclic aromatic hydrocarbons (PAHs) in urban and rural atmospheres of Guangzhou, China. Atmospheric Environment 39, 477-487. https:// doi.org/10.1016/j.atmosenv.2004.09.052

Binici H, Aksogan O, Shah T. 2005. Investigation of fibre reinforced mud brick as a building material. Construction and Building Materials 19, 313-318. https://doi. org/10.1016/j.conbuildmat.2004.07.013

Birch ME, Cary RA. 1996. Elemental carbon-based method for monitoring occupational exposures to particulate diesel exhaust. Aerosol Science and Technology 25, 221-241. https://doi.org/10.1080/02786829608965393

Boonyatumanond R, Murakami M, Wattayakorn G. 2007. Sources of polycyclic aromatic hydrocarbons (PAHs) in street dust in a tropical Asian mega-city, Bangkok, Thailand. Science of the Total Environment 384, 420432. https://doi.org/10.1016/j.scitotenv.2007.06.046

Briggs NL, Long CM. 2016. Critical review of black carbon and elemental carbon source apportionment in Europe and the United States. Atmospheric Environment 144, 409-427. https://doi.org/10.1016/J. ATMOSENV.2016.09.002

Caponero J, Tenorio JAS, Levendis YA, Carlson JB. 2003. Emissions of batch combustion of waste tire chips: The afterburner effect. Energy and Fuels 17, 225-239. https://doi.org/10.1021/ef0201331

Caponero J, Tenorio JAS, Levendis YA, Carlson JB. 2004. Emissions of batch combustion of waste tire chips: The hot flue-gas filtering effect. Energy and Fuels 18, 102-115. https://doi.org/10.1021/ef030043b

Caponero J, Tenorio JAS, Levendis YA, Carlson JB. 2005. Emissions of batch combustion of waste tire chips: The pyrolysis effect. Combustion Science and Technology 177, 347-381. https://doi. org/10.1080/00102200590900516

Chow JC, Watson JG, Lowenthal DH, Chen LA, Motallebi N. 2011. PM2.5 source profiles for black and organic carbon emission inventories. Atmospheric Environment 45, 5407-5414. https://doi.org/10.1016/j. atmosenv.2011.07.011

De Marini DM, Lemieux PM, Ryan JV, Brooks LR, Williams RW. 1994. Mutagenicity and chemical analysis of 
emissions from the open burning of scrap rubber tires. Environmental Science and Technology 28, 136-141. https://doi.org/10.1021/es00050a018

De Oliveira Alves N, de Souza Hacon S, de Oliveira Galvão MF, Simões Peixotoc M, Artaxo P, de Castro Vasconcellos P, et al. 2014. Genetic damage of organic matter in the Brazilian Amazon: A comparative study between intense and moderate biomass burning. Environmental Research 130, 51-58. https://doi. org/10.1016/j.envres.2013.12.011

Downard J, Singh A, Bullard RL, Jayarathne T, Rathnayake CM, Simmons DL, et al. 2015. Uncontrolled combustion of shredded tires in a landfill-Part 1: Characterization of gaseous and particulate emissions. Atmospheric Environment 104, 195-204. https://doi. org/10.1016/j.atmosenv.2014.12.059

Durant JL, Busby WF, Lafleur AL, Penman BW, Crespi CL. 1996. Human cell mutagenicity of oxygenated, nitrated and unsubstituted polycyclic aromatic hydrocarbons associated with urban aerosols. Mutation Research-Genetic Toxicology 371, 123-157. https:// doi.org/10.1016/S0165-1218(96)90103-2

Garshick E, Laden F, Hart JE, Rosner B, Smith TJ, Dockery DW, Speizer FE. 2004. Lung cancer in railroad workers exposed to diesel exhaust. Environmental Health Perspectives 112, 1539-1543. https://doi. org/10.1289/ehp.7195

Giere R, LaFree ST, Carleton LE, Tishmack JK. 2004. Environmental impact of energy recovery from waste tyres. Geological Society, London, Special Publications 236, 475-498. https://doi.org/10.1144/GSL. SP.2004.236.01.26

González-Sepúlveda E, Loyola-Sepúlveda R, Neira-Hinojosa J, Neira-González F. 2013. Contenido, distribución y origen de hidrocarburos en sedimentos de tres lagunas urbanas de concepción-Chile. Química Nova 36, 669-674. https://doi.org/10.1590/S010040422013000500010

Grimmer G, Jacob J, Naujack KW. 1983. Profile of the polycyclic aromatic compounds from crude oils. Fresenius' Journal of Analytical Chemistry 314, 29-36. http://dx.doi.org/10.1007/BF00476507

IARC. 1989. Diesel and gasoline engine exhausts and some nitroarenes. In: IARC Monographs on the Evaluation of Carcinogenic Risk to Humans 46, 1-467. https://publications.iarc.fr/64

INECC. 2016. Regional level market analysis of the construction sector and pilot project based on a public policy portfolio in order to reduce SLCP of traditional brickyards in Mexico. Final report. Instituto Nacional de Ecología y Cambio Climático, Mexico. Available at: https://www.gob.mx/cms/uploads/attachment/ file/252837/Final_report_pub_final_290817.pdf

INEGI. 2017. Directorio estadístico nacional de unidades económicas. Instituto Nacional de Estadística y Geografía, Mexico. Available at: https://www.inegi. org.mx/app/mapa/denue/ (last accessed on January 29, 2020).

IPOMEX. [2013]. Plan de desarrollo municipal 20132015. Temascalcingo. Información Pública de Oficio Mexiquense. Available at: https://www.ipomex.org. $\mathrm{mx} /$ recursos/ipo/files_ipo/2015/47/12/0c4145de8ff58e229ac09a08737ea9b1.pdf

Jakovljević I, Pehnec G, Vađić V, Čačković M, Tomašić V, Jelinić JD. 2018. Polycyclic aromatic hydrocarbons in PM10, PM2.5 and PM1 particle fractions in an urban area. Air Quality, Atmosphere Health 11, 843-854. https://doi.org/10.1007/s11869-018-0603-3

Khalili NR, Scheff PA, Holsen TM. 1995. PAH source fingerprints for coke ovens, diesel and, gasoline engines, highway tunnels, and wood combustion emissions. Atmospheric Environment 29, 533-542. https://doi. org/10.1016/1352-2310(94)00275-P

Kocbach A, Li Y, Yttri KE, Cassee FR, Schwarze PE, Namork E. 2006. Physicochemical characterization of combustion particles from vehicle exhaust and residential wood smoke. Particle and Fibre Toxicology 10, 1-10. https://doi.org/10.1186/1743-8977-3-1

Le HA, Oanh NTK. 2010. Integrated assessment of brick kiln emission impacts on air quality. Environmental Monitoring and Assessment 171, 381-394. https://doi. org/10.1007/s10661-009-1285-y

Lemieux PM, Lutes CC, Santoianni DA. 2004. Emissions of organic air toxics from open burning: A comprehensive review. Progress in Energy and Combustion Science 30, 1-32. https://doi.org/10.1016/j. pecs.2003.08.001

Li Z, Chen L, Liu S, Ma H, Wang L, An C, Zhang R. 2016. Characterization of PAHs and PCBs in fly ashes of eighteen coal-fired power plants. Aerosol and Air Quality Research 16, 3175-3186. https://doi.org/10.4209/ aaqr.2016.10.0430

Li Z, Fan L, Wang L, Ma H, Hu Y, Jiang Y, et al. 2018. PAH Profiles of emitted ashes from indoor biomass burning across the Beijing-Tianjin-Hebei region and implications on source identification. Aerosol and Air 
Quality Research 18, 749-761.https://aaqr.org/articles/ aaqr-17-12-oa-0588

Lönnermark A, Blomqvist P. 2005. Emissions from tyre fires. Report to the Swedish Rescue Services Agency, 43. Available at: https://www.diva-portal.org/smash/ get/diva2:962334/FULLTEXT01.pdf (last accessed on January 3, 2020).

Martínez-Salinas RI, Leal ME, Batres-Esquivel LE, Domínguez-Cortinas G, Calderón J, Díaz-Barriga F, Pérez-Maldonado IN. 2010. Exposure of children to polycyclic aromatic hydrocarbons in Mexico: Assessment of multiple sources. International Archives of Occupational and Environmental Health 83, 617-623. https://doi.org/10.1007/s00420-009-0482-x

Masiol M, Hofer A, Squizzato S, Piazza R, Rampazzo G, Pavoni B. 2012. Carcinogenic and mutagenic risk associated to airborne particle-phase polycyclic aromatic hydrocarbons: A source apportionment. Atmospheric Environment 60, 375-382. https://doi.org/10.1016/j. atmosenv.2012.06.073

Mille G, Asia L, Guiliano M, Malleret L, Doumenq P. 2007. Hydrocarbons in coastal sediments from the Mediterranean Sea (Gulf of Fos area, France). Marine Pollution Bulletin 54, 566-575. https://doi. org/10.1016/j.marpolbul.2006.12.009

Millogo Y, Morel J, Aubert J, Ghavami K. 2014. Experimental analysis of pressed adobe blocks reinforced with Hibiscus cannabinus fibers. Construction and Building Materials 52, 71-78. https://doi.org/http:// dx.doi.org/10.1016/j.conbuildmat.2013.10.094

Mugica V, Hernández S, Torres M, García R. 2010. Seasonal variation of polycyclic aromatic hydrocarbon exposure levels in Mexico City. Journal of the Air Waste Management Association 60, 548-555. https:// doi.org/10.3155/1047-3289.60.5.548

Mugica-Álvarez V, Santiago-de la Rosa N, Figueroa-Lara J, Flores-Rodríguez J, Torres-Rodríguez M, MagañaReyes M. 2015. Emissions of PAHs derived from sugarcane burning and processing in Chiapas and Morelos, Mexico. Science of the Total Environment 527-528, 474-482. https://doi.org/10.1016/j.scitotenv.2015.04.089

Nguyen TC, Loganathan P, Nguyen TV, Vigneswaran S, Kandasamy J, Slee D, et al. 2014. Polycyclic aromatic hydrocarbons in road-deposited sediments, water sediments, and soils in Sydney, Australia: Comparisons of concentration distribution, sources and potential toxicity. Ecotoxicology and Environmental Safety 104,
339-348. https://doi.org/http://dx.doi.org/10.1016/j. ecoenv.2014.03.010

Nisbet I, Lagoy P. 1992. Toxic equivalency factors (TEFs) for polycyclic aromatic hydrocarbons (PAHs). Regulatory Toxicology and Pharmacology 16, 290-300. https://doi.org/10.1016/0273-2300(92)90009-X

SSA. 2014. NOM-025-SSA1-2014, Salud ambiental. Valores límite permisibles para la concentración de partículas suspendidas PM10 y PM2.5 en el aire ambiente y criterios para su evaluación. Secretaría de Salud. Diario Oficial de la Federación, Mexico, August 20.

Pandey PK, Patel KS, Lenicek J. 1999. Study of an urban-industrial location in India. Environmental Monitoring and Assessment 59, 287-319. https://doi. org/10.1023/A:1006169605672

Pirnie M. 1991. Air emissions associated with the combustion of scrap tires for energy recovery. Prepared for the Ohio Air Quality Development Authority. Malcolm Pirnie, Columbus, OH, 67 pp.

Pongpiachan S, Hattayanone M, Cao J. 2017. Effect of agricultural waste burning season on PM2.5bound polycyclic aromatic hydrocarbon (PAH) levels in Northern Thailand. Atmospheric Pollution Research 8, 1069-1080. https://doi.org/10.1016/j. apr.2017.04.009

Pope C, Dockery D. 2006. Health effects of fine particulate air pollution: Lines that connect. Journal of the Air and Waste Management Association 56, 709-742. https:// doi.org/10.1080/10473289.2006.10464485

Querol X, Alastuey A, Rodríguez S, Plana F, Mantilla E, Ruiz CR. 2001. Monitoring of PM10 and PM2.5 around primary particulate anthropogenic emission sources. Atmospheric Environment 35, 845-858. https://doi.org/10.1016/S1352-2310(00)00387-3

Rajput P, Sarin MM, Rengarajan R, Singh D. 2011. Atmospheric polycyclic aromatic hydrocarbons (PAHs) from post-harvest biomass burning emissions in the Indo-Gangetic Plain: Isomer ratios and temporal trends. Atmospheric Environment 45, 6732-6740. https://doi. org/10.1016/j.atmosenv.2011.08.018

Ravindra K, Bencs L, Wauters E, De Hoog J, Deutsch F, Roekens E, et al. 2006. Seasonal and site-specific variation in vapour and aerosol phase PAHs over Flanders (Belgium) and their relation with anthropogenic activities. Atmospheric Environment 40, 771-785. https:// doi.org/10.1016/j.atmosenv.2005.10.011

Ravindra K, Sokhi R. 2008. Atmospheric polycyclic aromatic hydrocarbons: Source attribution, 
emission factors and regulation. Atmospheric Environment 42, 2895-2921. https://doi.org/10.1016/j. atmosenv.2007.12.010

Reisman JI, Lemieux PM. 1997. Emisiones al aire de la combustión de llantas usadas. Report for the US-Mexico Border Information Center in Air Pollution-USEPA, 124 pp. Available at: https://www3.epa.gov/ttncatc1/ cica/files/tire_esp.pdf (last accessed on January 10, 2020).

Rogge WF, Hildemann LM, Mazurek MA, Cass GR. 1993. Sources of fine organic aerosol. 2. Noncatalyst and catalyst-equipped automobiles and heavy-duty diesel trucks. Environmental Science and Technology 27, 636-651. https://doi.org/10.1021/es00041a007

Ruvalcaba-Sil J, Ontalba Salamanca M, Manzanilla L, Miranda J, Cañetas OJ, López C. 1999. Characterization of pre-Hispanic pottery from Teotihuacan, Mexico, by a combined PIXE-RBS and XRD analysis. Nuclear Instruments and Methods in Physics Research B 150, 591-596. https://doi.org/10.1016/ S0168-583X(98)01072-6

Schnelle K, Sklorz M, Peters A, Cyrys J, Zimmermann R. 2005. Analysis of particle-associated semi-volatile aromatic and aliphatic hydrocarbons in urban particulate matter on a daily basis. Atmospheric Environment 39, 7702-7714. https://doi.org/10.1016/j. atmosenv.2005.04.001

Sicre M, Marty J, Saliot A. 1987. Aliphatic and aromatic hydrocarbons in different sized aerosols over the
Mediterranean Sea: Occurrence and origin. Atmospheric Environment 21, 2247-2259. https://doi. org/10.1016/0004-6981(87)90356-8

Skinder BM, Sheikh AQ, Pandit AK, Ganai BA. 2014. Brick kiln emissions and its environmental impact: A review. Ecology and the Natural Environment 6, 1-11. https://doi.org/10.5897/JENE2013.0423

USEPA. 1999. Compendium of methods for the determination of inorganic compounds in ambient air. U.S. Environmental Protection Agency, Cincinnati, OH. Available at: https://www.epa.gov/amtic/compendium-methods-determination-inorganic-compounds-ambient-air

Valle-Hernández BL, Mugica-Álvarez V, Salinas-Talavera E, Amador-Muñoz O, Murillo-Tovar MA, Villalobos-Pietrini R, De Vizcaya-Ruz A. 2010. Temporal variation of nitro-polycyclic aromatic hydrocarbons in PM10 and PM2.5 collected in northern Mexico City. Science of the Total Environment 408, 5429-5438. https://doi.org/10.1016/j.scitotenv.2010.07.065

Wang Z, Li K, Lambert P, Yang C. 2007. Identification, characterization and quantitation of pyrogenic polycyclic aromatic hydrocarbons and other organic compounds in tire fire products. Journal of Chromatography A 1139, 14-26. https://doi.org/10.1016/j. chroma.2006.10.085

Williams E. 2018. Ceramic ethnoarchaeology in Huáncito, Michoacán, Mexico. Ancient Mesoamerica 29, 11-44. https://doi.org/10.1017/S0956536117000293 